\title{
Neutral tripodal receptors towards efficient trapping of oxalate
}

\author{
RANJAN DUTTA, BIJIT CHOWDHURY, PURNANDHU BOSE and PRADYUT GHOSH* \\ Department of Inorganic Chemistry, Indian Association for the Cultivation of Science, 2A and 2B Raja S C \\ Mullick Road, Kolkata 700 032, India \\ e-mail: icpg@iacs.res.in
}

MS received 27 March 2014; revised 20 June 2014; accepted 29 June 2014

\begin{abstract}
Tris(2-aminoethyl)amine (TREN) based pentafluorophenyl urea and 4-cyanophenyl thiourea receptors have shown encapsulation of oxalate $\left(\mathrm{C}_{2} \mathrm{O}_{4}^{2-}\right)$ in semi-aqueous environment. A single crystal X-ray study shows trapping of planar conformer of $\mathrm{C}_{2} \mathrm{O}_{4}^{2-}$ in both the cases. Further solution state binding of $\mathrm{C}_{2} \mathrm{O}_{4}^{2-}$ is probed by ${ }^{1} \mathrm{H}-\mathrm{NMR}$ titration study in semi-aqueous solvent.
\end{abstract}

Keywords. Anion receptor; urea; thiourea; oxalate recognition; single crystal x-ray diffraction; ${ }^{1} \mathrm{H}-\mathrm{NMR}$ titration.

\section{Introduction}

Recognition of carboxylates is important as they play vital roles in various metabolic processes. ${ }^{1}$ Simplest dicarboxylate oxalate $\left(\mathrm{C}_{2} \mathrm{O}_{4}^{2-}\right)$ is a nutrient in human body. ${ }^{2}$ However excess of oxalate causes renal failure, kidney stones, etc. ${ }^{3}$ Besides its biological and environmental relevance, oxalate is a common analytical reagent. Dianionic form of oxalate $\left(\mathrm{C}_{2} \mathrm{O}_{4}^{2-}\right)$ can exist as staggered or planar conformer. Rotational energy barrier between these two conformers is $2-6 \mathrm{kcal} / \mathrm{mol}^{4}{ }^{4 \mathrm{a}-\mathrm{b}}$ Although staggered conformer is the stable form of $\mathrm{C}_{2} \mathrm{O}_{4}^{2-}$, most of the structural reports show presence of planar $\mathrm{C}_{2} \mathrm{O}_{4}^{2-}$ conformer. ${ }^{4 \mathrm{~b}}$ Charged polyammonium receptors are familiar systems for binding of $\mathrm{C}_{2} \mathrm{O}_{4}^{2-}$. Metal based receptors have also been explored for $\mathrm{C}_{2} \mathrm{O}_{4}^{2-}$ sensing in recent times. ${ }^{6}$ Very few synthetic neutral receptors have been designed for the recognition of $\mathrm{C}_{2} \mathrm{O}_{4}^{2-}{ }^{7}$ Tren based tripodal urea/thiourea receptors have attracted a great deal of attention for anion recognition in recent times. ${ }^{8}$ Although these class of receptors are explored for anion complexation in nonaqueous medium, recently binding propensity of these receptors in aqueous medium are also established. ${ }^{8 \mathrm{a}, \mathrm{e}, \mathrm{n}, \mathrm{o}}$ Interestingly most of the receptors tend to form dimeric capsular assembly upon encapsulation of anionic guests like sulphate, phosphates and carbonate. ${ }^{8 p, r, s}$ In our ongoing effort for anion recognition chemistry, we have recently reported recognition of $\mathrm{C}_{2} \mathrm{O}_{4}^{2-}$ by two structurally analogous tripodal urea receptors in semiaqueous media where trapping of staggered $v s$. planar

*For correspondence
$\mathrm{C}_{2} \mathrm{O}_{4}^{2-}$ conformer is demonstrated by single crystal $\mathrm{X}$-ray structural analysis. ${ }^{8 t}$ Herein, we show solid and solution states encapsulation studies of $\mathrm{C}_{2} \mathrm{O}_{4}^{2-}$ by two other tripodal anion receptors, pentafluorophenyl substituted urea (L1) and 4-cyanophenyl substituted thiourea (L2) and have compared the same with the recently published $\mathrm{C}_{2} \mathrm{O}_{4}^{2-}$ complexes of $\mathbf{L 3}$ and $\mathbf{L 4}$.

\section{Experimental}

${ }^{1} \mathrm{H}-\mathrm{NMR}$ and ${ }^{13} \mathrm{C}-\mathrm{NMR}$ spectra of oxalate complexes of $\mathbf{L 1}$ and $\mathbf{L} 2$ i.e., 1 and $\mathbf{2}$ were recorded on Bruker $300 \mathrm{MHz}$ FT-NMR spectrometer (model: DPX-300) in DMSO- $d_{6}$ and $\mathrm{CDCl}_{3}$ respectively at $25^{\circ} \mathrm{C}$. Solvents, tetrabutylammonium iodide and potassium oxalate were purchased from Spectrochem Ltd., India. Chemical shifts for ${ }^{1} \mathrm{H}$ and ${ }^{13} \mathrm{C}$-NMR were reported in parts per million (ppm), calibrated to the residual solvent peak set, with coupling constants reported in Hertz $(\mathrm{Hz})$.

\subsection{Synthesis of complex 1}

Receptor $\mathbf{L 1}$ and TBAI (2 equiv.) are dissolved in DMSO/5\% $\mathrm{H}_{2} \mathrm{O}$ solvent mixture and excess of $\mathrm{K}_{2} \mathrm{C}_{2} \mathrm{O}_{4}$, $2 \mathrm{H}_{2} \mathrm{O}$ is added to it. The reaction mixture is then stirred for $1 \mathrm{~h}$ and filtered for crystallization. Block shape crystals of complex $1\left[(\mathbf{L 1})_{2} \cdot\left(\mathrm{C}_{2} \mathrm{O}_{4}\right)\right](\mathrm{TBA})_{2}$ appear within a week in good yield (70\%). ${ }^{1} \mathrm{H}-\mathrm{NMR}$ (300 MHz, DMSO- $\left.d_{6}\right): 8.94(\mathrm{NH}, 3 \mathrm{H}), 7.38(\mathrm{NH}, 3 \mathrm{H}), 3.13-3.19$ $\left(8 \mathrm{H}, \mathrm{NCH}_{2} \mathrm{CH}_{2} \mathrm{CH}_{2} \mathrm{CH}_{3}\right), 3.06\left(6 \mathrm{H}, \mathrm{NCH}_{2} \mathrm{CH}_{2}\right), 2.46$ (6H, $\left.\mathrm{NCH}_{2} \mathrm{CH}_{2}\right), 1.51-1.62\left(8 \mathrm{H}, \mathrm{NCH}_{2} \mathrm{CH}_{2} \mathrm{CH}_{2} \mathrm{CH}_{3}\right)$, 
1.25-1.37 (8H, $\left.\mathrm{NCH}_{2} \mathrm{CH}_{2} \mathrm{CH}_{2} \mathrm{CH}_{3}\right), 0.91-0.96(12 \mathrm{H}$, $\left.\mathrm{NCH}_{2} \mathrm{CH}_{2} \mathrm{CH}_{2} \mathrm{CH}_{3}\right) .{ }^{13} \mathrm{C}(75 \mathrm{MHz}$, DMSO-d $)$ 172.38, $155.19,144.99,141.73,139.80,138.99,136.51$, $135.69,115.72,58.05,54.73,38.49,29.47,23.59$, $19.75,14.01$

\subsection{Synthesis of complex 2}

Complex $2\left[(\mathbf{L 2})_{2} \cdot\left(\mathrm{C}_{2} \mathrm{O}_{4}\right)\right](\mathrm{TBA})_{2}$ is synthesized similarly like complex 1 . Yield: 50\%. ${ }^{1} \mathrm{H}-\mathrm{NMR}(300 \mathrm{MHz}$, $\left.\mathrm{CDCl}_{3}\right): 10.24(\mathrm{NHa}, 3 \mathrm{H}), 8.71(\mathrm{NHb}, 3 \mathrm{H}), 7.55-$ $7.58(6 \mathrm{H}, \mathrm{Ar}-\mathrm{CH}), 7.17-7.20(6 \mathrm{H}, \mathrm{Ar}-\mathrm{CH}), 3.66(6 \mathrm{H}$, $\left.\mathrm{NCH}_{2} \mathrm{CH}_{2}\right), 3.04-3.09\left(8 \mathrm{H}, \mathrm{NCH}_{2} \mathrm{CH}_{2} \mathrm{CH}_{2} \mathrm{CH}_{3}\right), 2.73$ (6H, $\left.\mathrm{NCH}_{2} \mathrm{CH}_{2}\right), 1.53-1.63\left(8 \mathrm{H}, \mathrm{NCH}_{2} \mathrm{CH}_{2} \mathrm{CH}_{2} \mathrm{CH}_{3}\right)$, 1.24-1.45 (8H, $\left.\mathrm{NCH}_{2} \mathrm{CH}_{2} \mathrm{CH}_{2} \mathrm{CH}_{3}\right), 0.97-1.01(12 \mathrm{H}$, $\left.\mathrm{NCH}_{2} \mathrm{CH}_{2} \mathrm{CH}_{2} \mathrm{CH}_{3}\right) .{ }^{13} \mathrm{C}-\mathrm{NMR}$ (75 $\mathrm{MHz}, \mathrm{CDCl}_{3}$ ) $180.96,171.91,144.52,132.01,122.46,119.38$, $105.40,135.69,115.72,59.03,53.94,42.75,23.89$, $19.78,13.66$

\section{$2.3 X$ - ray crystallography}

The crystallographic data and data collection details for complexes 1 (CCDC: 914150) and 2 (CCDC: 914148) are given below. A crystal of suitable size is selected from the mother liquor and immersed in paratone oil, then mounted on the tip of a glass fibre and cemented using epoxy resin. Intensity data for the crystals are collected using Mo $\mathrm{K} \alpha(1=0.7107 \AA)$ radiation on a Bruker SMART APEX diffractometer equipped with CCD area detector at $120 \mathrm{~K}$. The data integration and reduction are processed with SAINT ${ }^{9 a}$ software. An empirical absorption correction is applied to the collected reflections with SADABS. ${ }^{9 b}$ The structures are solved by direct methods using SHELXTL ${ }^{10}$ and refined by $\mathrm{F}^{2}$ by the full-matrix least-squares technique using the SHELXL-97 ${ }^{11}$ program package. Graphics are generated using PLATON, ${ }^{12}$ MERCURY $2.2^{13}$ and ORTEP3v2. The non-hydrogen atoms are treated anisotropically. Wherever possible, the hydrogen atoms are located on a difference Fourier map and refined. In other cases, the hydrogen atoms are geometrically fixed. Crystallographic parameters for complexes $\mathbf{1}$ and $\mathbf{2}$ are tabulated in supporting information (table S1).

\section{Results and Discussion}

Syntheses of the receptors L1-L4 (scheme 1) are reported previously. ${ }^{8 \mathrm{~d}, \mathrm{q}, \mathrm{t}}$ Complexes $\mathbf{1}$ and $\mathbf{2}$ are synthesized in good yield by the reaction of receptor, TBAI and excess $\mathrm{K}_{2} \mathrm{C}_{2} \mathrm{O}_{4}$ in DMSO/5\% $\mathrm{H}_{2} \mathrm{O}$ solvent mixture. Syntheses of complexes $\mathbf{3}$ and $\mathbf{4}$ are reported previously

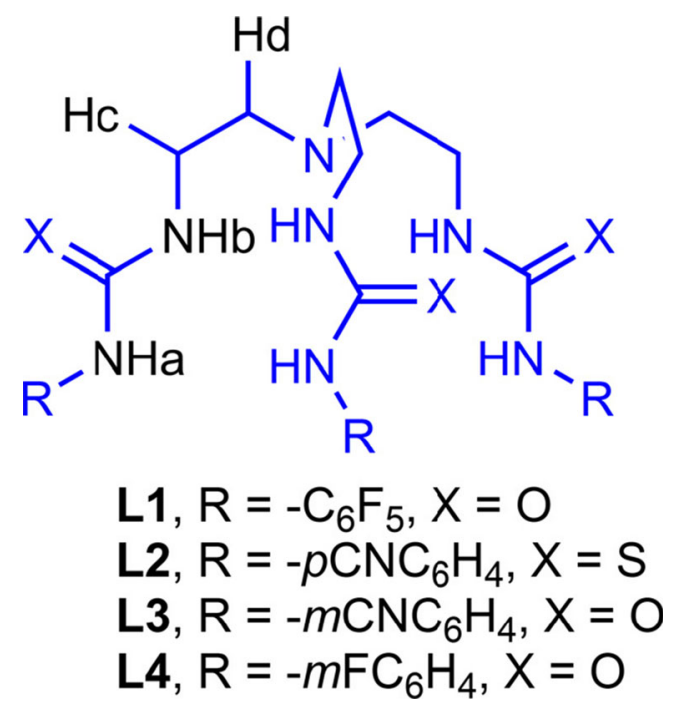

Scheme 1. Chemical structures of the receptors L1-L4

by our group. ${ }^{8 t}$ The detailed solid and solution states binding properties of $\mathbf{L} \mathbf{1}$ and $\mathbf{L} 2$ towards $\mathrm{C}_{2} \mathrm{O}_{4}^{2-}$ are discussed in the next section.

\subsection{Structural description of complex 1}

Crystals of complex $\mathbf{1}$ are obtained by the reaction of $\mathbf{L 1}$ and TBAI ( $\sim 2$ equiv.) with excess of $\mathrm{K}_{2} \mathrm{C}_{2} \mathrm{O}_{4}$ in $\mathrm{DMSO} / 5 \%$ water solvent mixture. Complex 1 crystallizes in triclinic crystal system with $\mathrm{P}-1$ space group. Asymmetric unit of complex $\mathbf{1}$ contains two L1 units, one $\mathrm{C}_{2} \mathrm{O}_{4}^{2-}$, two TBA countercations and two DMSO as solvent of crystallization. Two units of $\mathbf{L} \mathbf{1}$ form a dimeric capsular assembly that completely encapsulates one $\mathrm{C}_{2} \mathrm{O}_{4}^{2-}$ in its cavity (figure 1 ). Binding of $\mathrm{C}_{2} \mathrm{O}_{4}^{2-}$ in complex 1 is assisted by twelve $\mathrm{N}-\mathrm{H}$... O interactions between four oxygen atoms of $\mathrm{C}_{2} \mathrm{O}_{4}^{2-}$ and twelve $-\mathrm{NH}$ groups of two L1. Four oxygen atoms of the encapsulated $\mathrm{C}_{2} \mathrm{O}_{4}^{2-}$ namely $\mathrm{O} 9, \mathrm{O} 10, \mathrm{O} 11$ and $\mathrm{O} 12$ are involved in three $\mathrm{N}-\mathrm{H} \cdots \mathrm{O}$ interactions each. The $\mathrm{N}$. . O bond distances in $\mathbf{1}$ vary from 2.84 to $3.04 \AA$, whereas the $\mathrm{N}-\mathrm{H} \cdots \mathrm{O}$ angles range from 153 to $169^{\circ}$ (table S2). The capsular dimension of $\mathbf{1}$ from apical $\mathrm{N}$... N distance is measured as $10.75 \AA$. The encapsulated $\mathrm{C}_{2} \mathrm{O}_{4}^{2-}$ in complex $\mathbf{1}$ is found to be a planar conformer of $\mathrm{C}_{2} \mathrm{O}_{4}^{2-}$. The torsion angle of planar $\mathrm{C}_{2} \mathrm{O}_{4}^{2-}$ conformer is measured to be $3.06^{\circ}$. The bond length around the central $\mathrm{C}-\mathrm{C}$ bond of $\mathrm{C}_{2} \mathrm{O}_{4}^{2-}$ is found to be $1.56 \AA$, which suggests single bond character of the $\mathrm{C}-\mathrm{C}$ bond (table 1 ). Interestingly $\mathrm{C}_{2} \mathrm{O}_{4}^{2-}$ encapsulation in complex $\mathbf{1}$ is also facilitated by orthogonal $\mathrm{C}-\mathrm{F} . \cdots \mathrm{C}=\mathrm{O}$ interaction ${ }^{14}$ (figure 2). Each $\mathrm{C}=\mathrm{O}$ group of the $\mathrm{C}_{2} \mathrm{O}_{4}^{2-}$ are in close contact with the C-F group of $-\mathrm{C}_{6} \mathrm{~F}_{5}$ ring. The $\mathrm{F} \cdots \mathrm{C}$ bond distance of two 


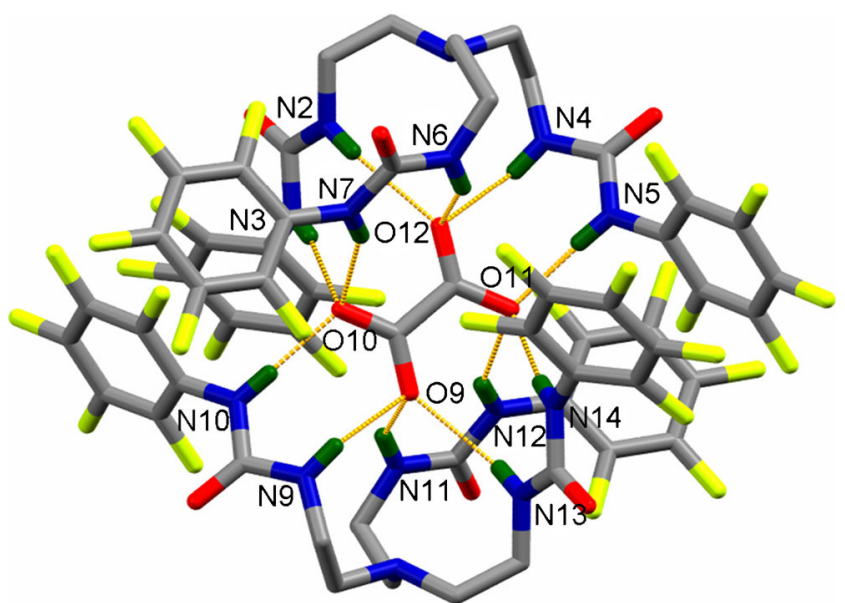

Figure 1. Crystal structure of complex 1 showing complete encapsulation of $\mathrm{C}_{2} \mathrm{O}_{4}^{2-}$ inside the dimeric capsular assembly of L1. Non-acidic hydrogens, tetrabutylammonium countercations and solvents are omitted for clarity.

orthogonal C-F. . C $=\mathrm{O}$ interactions are measured as $2.96 \AA$ for C9-F5 . . C91-O10 and $2.98 \AA$ for C50$\mathrm{F} 26 \cdots \mathrm{C} 92-\mathrm{O} 11$. The $\mathrm{F} \cdots \mathrm{C}=\mathrm{O}$ angles associated with the two $\mathrm{C}-\mathrm{F} \cdots \mathrm{C}=\mathrm{O}$ contacts are $92.36^{\circ}$ (F5 . . C 91 $\mathrm{O} 10)$ and $90.84^{\circ}$ (F26 ‥ C92-O11).

\subsection{Structural description of complex 2}

Complex $\mathbf{2}$ is synthesized similarly like $\mathbf{1}$, by reacting L2, TBAI and excess $\mathrm{K}_{2} \mathrm{C}_{2} \mathrm{O}_{4}$ in DMSO/5\% $\mathrm{H}_{2} \mathrm{O}$ solvent mixture. Unit of cell of complex 2 contains two $\mathbf{L} 2$ units, one $\mathrm{C}_{2} \mathrm{O}_{4}^{2-}$ and two TBA countercations. Dimeric assembly of $\mathbf{L 2}$ encapsulates one $\mathrm{C}_{2} \mathrm{O}_{4}^{2-}$ in complex $\mathbf{2}$ like complex 1 (figure 3). Each oxygen atom of the encapsulated $\mathrm{C}_{2} \mathrm{O}_{4}^{2-}$ involves in three $\mathrm{N}-\mathrm{H} \cdots \mathrm{O}$ interactions with the $-\mathrm{NH}$ group of $\mathbf{L 2}$, resulting total twelve $\mathrm{N}-\mathrm{H} \cdot \mathrm{O}$ contacts. The $\mathrm{N} \cdots \mathrm{O}$ bond distances in 2 range from 2.95 to $3.14 \AA$, whereas the N-H. . O angles vary from 150 to $178^{\circ}$ (table S3). The capsular dimension of $\mathbf{2}$ is smaller ( $10.08 \AA)$ than that of $\mathbf{1}$. The encapsulated $\mathrm{C}_{2} \mathrm{O}_{4}^{2-}$ in complex 2 is also planar $\mathrm{C}_{2} \mathrm{O}_{4}^{2-}$ conformer like $\mathbf{1}$. The torsion angle and central $\mathrm{C}-\mathrm{C}$ bond distance of the planar $\mathrm{C}_{2} \mathrm{O}_{4}^{2-}$ conformer are measured as $0.02^{\circ}$ and $1.49 \AA$ R respectively (table 1 ).

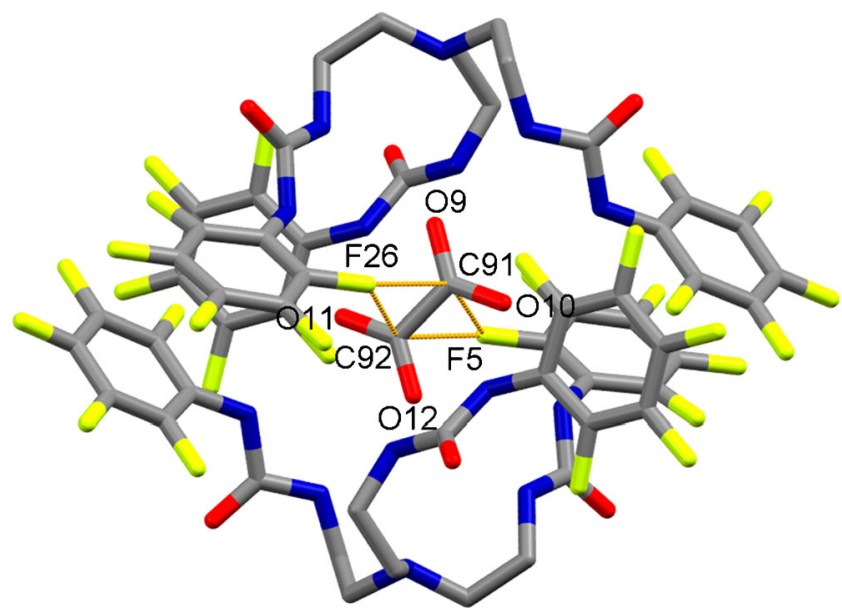

Figure 2. View of orthogonal $\mathrm{C}-\mathrm{F} \cdots \mathrm{C}=\mathrm{O}$ interactions in complex 1.

\subsection{Comparative structural description of complex $1-4$}

All the receptors form dimeric capsular assembly upon encapsulation of $\mathrm{C}_{2} \mathrm{O}_{4}^{2-}$ irrespective of ligand functionality. However the dimeric capsules differ in terms of conformation of encapsulated $\mathrm{C}_{2} \mathrm{O}_{4}^{2-}$ and capsular dimension. Structural analysis of $\mathrm{C}_{2} \mathrm{O}_{4}^{2-}$ complexes of L1, L2 and L4 reveal planar conformation of the encapsulated $\mathrm{C}_{2} \mathrm{O}_{4}^{2-}$. Planar nature of $\mathrm{C}_{2} \mathrm{O}_{4}^{2-}$ is evident from the dihedral angles of O-C-C-O bond of $\mathrm{C}_{2} \mathrm{O}_{4}^{2-}$, which are measured as $3.06,0.02$ and $0.12^{\circ}$ for complexes $\mathbf{1}$, 2 and 4 respectively (figure 5). Only in case of complex 3 , staggered $\mathrm{C}_{2} \mathrm{O}_{4}^{2-}$ conformer is obtained with torsion angle $68.8^{\circ}{ }^{8 \mathrm{t}}$ Capsular dimension of dimeric capsules vary substantially from moving planar to staggered $\mathrm{C}_{2} \mathrm{O}_{4}^{2-}$ conformer. Capsular dimension based on apical $\mathrm{N} \cdots \mathrm{N}$ distance is found to be highest for complex 4 having planar $\mathrm{C}_{2} \mathrm{O}_{4}^{2-}$ conformer, whereas staggered $\mathrm{C}_{2} \mathrm{O}_{4}^{2-}$ encapsulating capsule shows smallest capsular size of $9.82 \AA^{8 t}$ (figures 4 and 5). Staggered vs. planar conformer encapsulation is observed in single crystal $\mathrm{X}$-ray studies. Thus, this is purely a solid state property of the complexes. Attached moiety in the urea/thiourea receptor influences the electronic as well as steric properties of the receptors. This could affect the guest

Table 1. O-C-C-O torsion angle, C-C bond distance of $\mathrm{C}_{2} \mathrm{O}_{4}^{2-}$ and capsular dimension of complexes $\mathbf{1 - 4}$.

\begin{tabular}{lccc}
\hline Compound & Torsion angle $\left(^{\circ}\right)$ & C-C distance $(\AA)$ & Capsular dimension $(\AA)$ \\
\hline Complex 1 & 3.06 & 1.56 & 10.75 \\
Complex 2 & 0.02 & 1.49 & 10.08 \\
Complex 3 & 68.81 & 1.50 & 9.82 \\
Complex 4 $^{8 \mathrm{t}}$ & 0.12 & 1.58 & 10.82 \\
$\mathrm{~K}_{2} \mathrm{C}_{2} \mathrm{O}_{4}, 2 \mathrm{H}_{2} \mathrm{O}$ & 0.00 & 1.59 & - \\
\hline
\end{tabular}




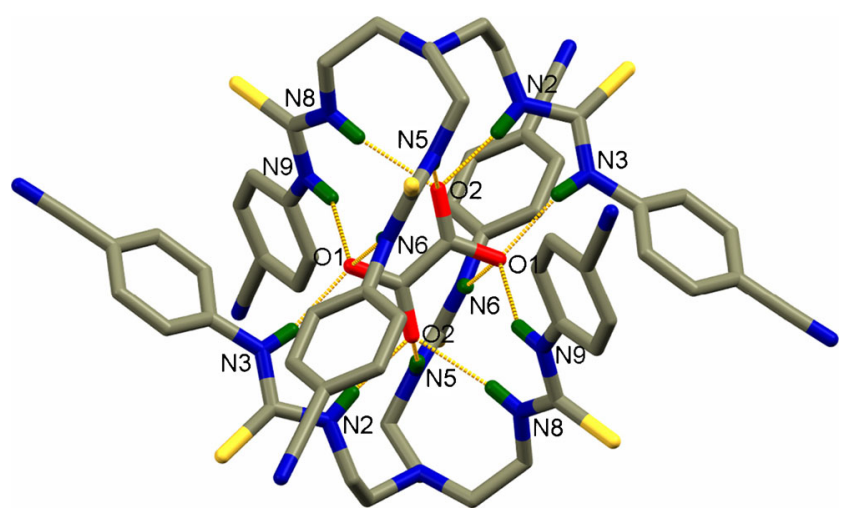

Figure 3. Crystal structure of complex 2 showing complete encapsulation of $\mathrm{C}_{2} \mathrm{O}_{4}^{2-}$ via twelve $\mathrm{N}-\mathrm{H} \cdots \mathrm{O}$ interactions. Non-acidic hydrogens and tetrabutylammonium countercations are omitted for clarity. binding pattern in dimeric capsules in solid state which is reflected in this particular case. Capsular sizes of the oxalate capsules depend on the substituent nature of the receptor. For example, complex $\mathbf{3}$ shows similar capsular size as that of $\mathrm{SO}_{4}^{2-}$ complex of $\mathbf{L 3}{ }^{8 \mathrm{~b}}$ Similarly, $\mathrm{HAsO}_{4}^{2-}$ complex of $\mathbf{L} \mathbf{1}$ shows capsular sizes similar to complex $1 .^{8 \mathrm{n}}$

\subsection{Solution state $\mathrm{C}_{2} \mathrm{O}_{4}^{2-}$ binding study}

Solution state binding study of $\mathbf{L} \mathbf{1}$ and $\mathbf{L 2}$ with $\mathrm{C}_{2} \mathrm{O}_{4}^{2-}$ is carried out by ${ }^{1} \mathrm{H}-\mathrm{NMR}$ titration. A solution of $\mathbf{L} \mathbf{1}$ in DMSO- $d_{6} / \mathrm{D}_{2} \mathrm{O}(9: 1, \mathrm{v} / \mathrm{v})$ is titrated against a solution of $\mathrm{K}_{2} \mathrm{C}_{2} \mathrm{O}_{4}$ in $\mathrm{D}_{2} \mathrm{O} / \mathrm{DMSO}-d_{6}(1.1: 1$, v/v) solvent mixture. Gradual upfield shift of $\mathrm{CHc} / \mathrm{d}$ proton is observed upon
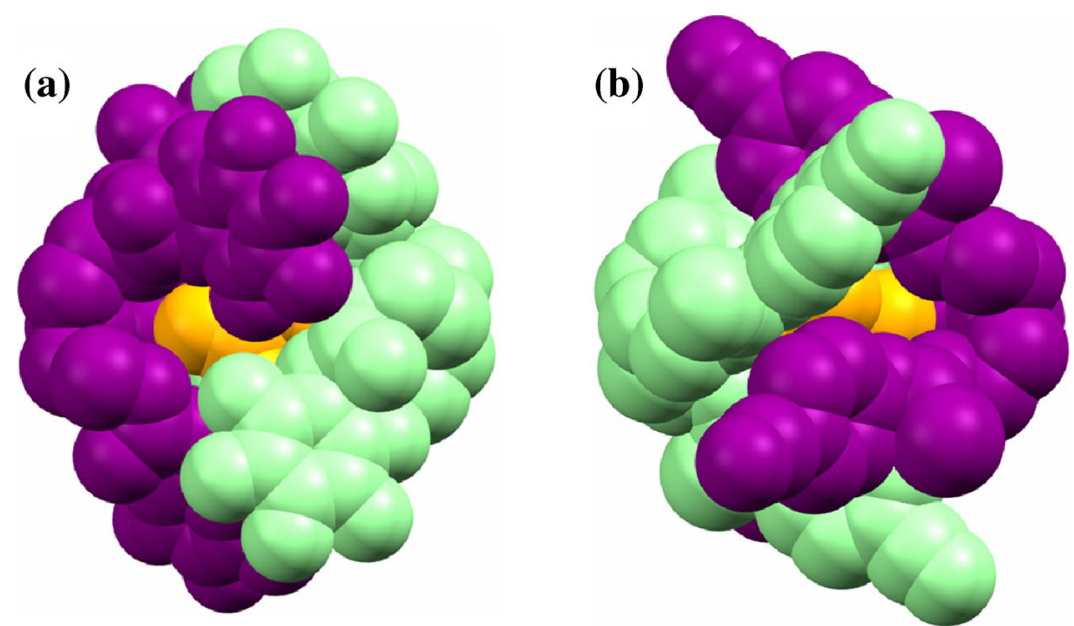

$$
N \cdot N=10.75 A
$$

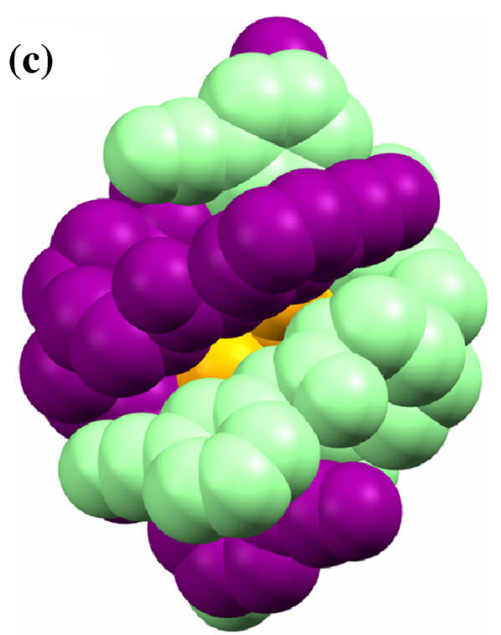

$$
\mathbf{N} \cdots \mathbf{N}=9.82 \AA
$$

$$
\mathbf{N} \cdots \mathbf{N}=10.08 \AA
$$

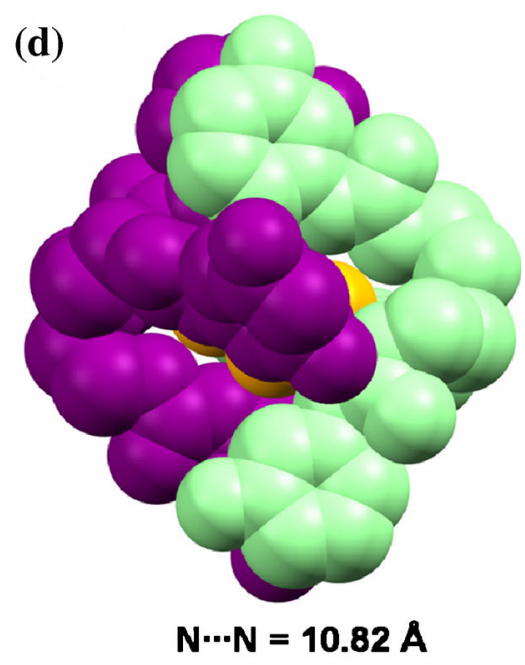

Figure 4. Comparative structural view of (a) complex 1; (b) complex 2; (c) complex $\mathbf{3}$ and; (d) complex $\mathbf{4}$ with the capsular dimensions. 

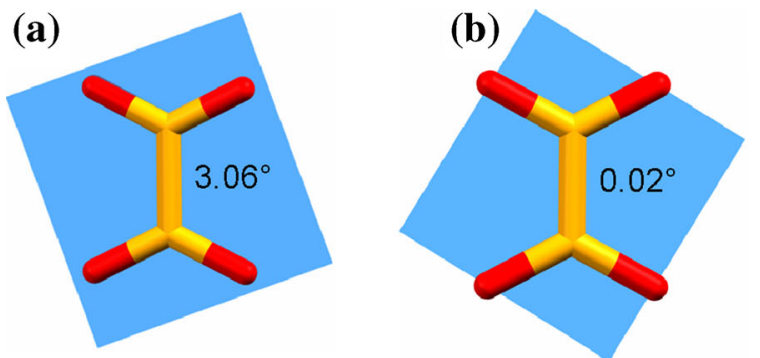

(c)

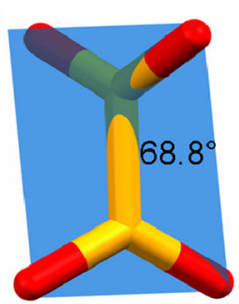

(d)

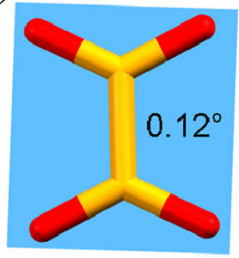

Figure 5. Close-up view of $\mathrm{C}_{2} \mathrm{O}_{4}^{2-}$ conformer in (a) complex 1; (b) complex 2; (c) complex $\mathbf{3}$ and; (d) complex $\mathbf{4}$ with their respective torsion angle.

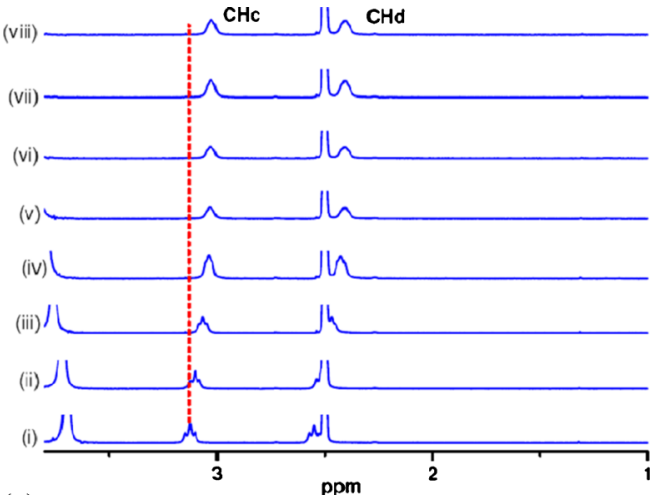

(a)

Figure 6. (a) Partial ${ }^{1} \mathrm{H}-\mathrm{NMR}(300 \mathrm{MHz})$ spectral changes of $\mathbf{L 1}$ in DMSO- $d_{6} / \mathrm{D}_{2} \mathrm{O}(9: 1)(\mathrm{v} / \mathrm{v})$ with added standard $\mathrm{K}_{2} \mathrm{C}_{2} \mathrm{O}_{4}$ solution in DMSO- $d_{6} / \mathrm{D}_{2} \mathrm{O}(1: 1.1)(298 \mathrm{~K})\left([\mathbf{L 1}]_{0}=3.41 \mathrm{mM}\right)$. Ratio of concentration $\left[\mathrm{C}_{2} \mathrm{O}_{4}^{2-}\right] /[\mathbf{L 1}]$ : (i) 0 , (ii) 0.13 , (iii) 0.39 , (iv) 0.65 , (v) 0.92 , (vi) 1.17 , (vii) 1.44 , (viii) 1.70; (b) Job's plot for $\mathbf{L 1}$ with $\mathrm{K}_{2} \mathrm{C}_{2} \mathrm{O}_{4}$ in DMSO- $d_{6} / \mathrm{D}_{2} \mathrm{O}$ (1:1.1) ([L1] is varied from 3.41 to 2.67 $\mathrm{mM}$ by the addition of aliquots of $27.92 \mathrm{mM} \mathrm{K}_{2} \mathrm{C}_{2} \mathrm{O}_{4}$ ).

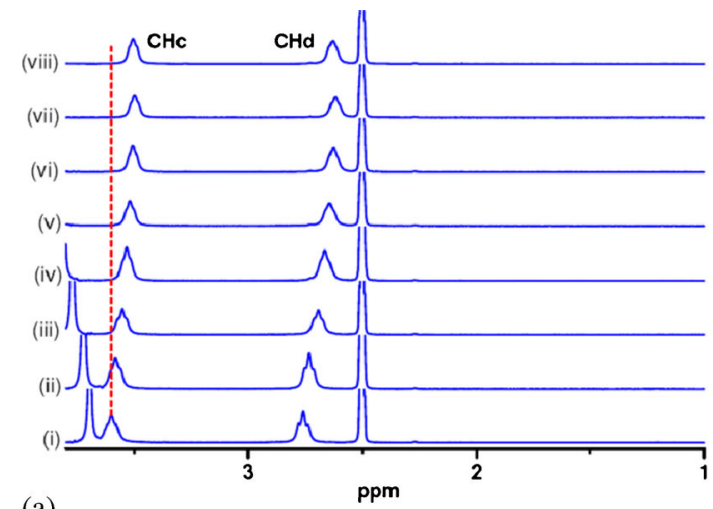

(a)

Figure 7. (a) Partial ${ }^{1} \mathrm{H}-\mathrm{NMR}(300 \mathrm{MHz})$ spectral changes of $\mathbf{L} 2$ in DMSO- $d_{6} / \mathrm{D}_{2} \mathrm{O}(9: 1)(\mathrm{v} / \mathrm{v})$ with added standard $\mathrm{K}_{2} \mathrm{C}_{2} \mathrm{O}_{4}$ solution in DMSO- $d_{6} / \mathrm{D}_{2} \mathrm{O}(1: 1.1)(298 \mathrm{~K})\left([\mathbf{L} 2]_{0}=5.49 \mathrm{mM}\right)$. Ratio of concentration $\left[\mathrm{C}_{2} \mathrm{O}_{4}^{2-}\right] /[\mathbf{L 2}]$ : (i) 0 , (ii) 0.11 , (iii) 0.32 , (iv) 0.54 , (v) 0.76, (vi) 0.97, (vii) 1.19, (viii) 1.41 ; (b) Job's plot for $\mathbf{L} 2$ with $\mathrm{K}_{2} \mathrm{C}_{2} \mathrm{O}_{4}$ in DMSO- $d_{6} / \mathrm{D}_{2} \mathrm{O}$ (1:1.1) ([L2] is varied from 5.49 to 4.22 $\mathrm{mM}$ by the addition of aliquots of $29.67 \mathrm{mM} \mathrm{K}_{2} \mathrm{C}_{2} \mathrm{O}_{4}$ ). 
Table 2. Binding constant and free energy change of L1$\mathbf{L 4}$ with $\mathrm{C}_{2} \mathrm{O}_{4}^{2-}$.

\begin{tabular}{lcc}
\hline Compound & $\log \mathrm{K}$ & $\Delta \mathrm{G}(\mathrm{kcal} / \mathrm{mol})$ \\
\hline L1 & 4.26 & -5.85 \\
L2 & 5.37 & -7.37 \\
L3 & $4.82^{8 \mathrm{t}}$ & -6.62 \\
L4 & $4.29^{8 \mathrm{t}}$ & -5.89 \\
\hline
\end{tabular}

addition of aliquots of $\mathrm{C}_{2} \mathrm{O}_{4}^{2-}$. On the other hand, $\mathrm{NHa} / \mathrm{b}$ peaks disappear during titration. In case of $\mathbf{L} 1$, upfield shift of $0.095 \mathrm{ppm}$ is observed for $\mathrm{CHc}$ upon addition of $\sim 1$ equivalent of $\mathrm{C}_{2} \mathrm{O}_{4}^{2-}$ (figures $6 \mathrm{a}$ and S5). Whereas in case of $\mathbf{L 2}, 0.097 \mathrm{ppm}$ upfield shift of $\mathrm{CHc}$ proton is found upon addition of $\sim 1$ equivalent of $\mathrm{C}_{2} \mathrm{O}_{4}^{2-}$ (figures 7a and S6). Job's plot analysis based $\mathrm{CHc}$ proton shift shows $1: 1$ binding between $\mathbf{L 1} / \mathbf{L} 2$ with $\mathrm{C}_{2} \mathrm{O}_{4}^{2-}$ (figures $6 \mathrm{~b}$ and $7 \mathrm{~b}$ ). Both the receptors $\mathbf{L} \mathbf{1}$ and L2 show high binding affinity $\left(\sim 10^{4}\right)$ towards $\mathrm{C}_{2} \mathrm{O}_{4}^{2-}$ in DMSO- $d_{6} / \mathrm{D}_{2} \mathrm{O}(9: 1, \mathrm{v} / \mathrm{v})$ (table 2). Similar order of binding constant values for $\mathrm{C}_{2} \mathrm{O}_{4}^{2-}$ are also reported previously with other tripodal urea receptors $\mathbf{L 3}$ and $\mathbf{L 4}{ }^{8 \mathrm{t}}$

\section{Conclusion}

Thus we have demonstrated efficient encapsulation of two conformers of $\mathrm{C}_{2} \mathrm{O}_{4}^{2-}$ in semi-aqueous solvent by simple tripodal urea/thiourea receptors. Further, this study generalizes the $\mathrm{C}_{2} \mathrm{O}_{4}^{2-}$ encapsulation by simple tripodal neutral receptors with urea/thiourea functionalities. The single crystal X-ray structural study reveals trapping of $\mathrm{C}_{2} \mathrm{O}_{4}^{2-}$ inside the dimeric capsular assembly of the receptors by multiple N-H . . O interactions. Three of the receptors show evidence of planar $\mathrm{C}_{2} \mathrm{O}_{4}^{2-}$ encapsulation whereas one receptor encapsulates staggered $\mathrm{C}_{2} \mathrm{O}_{4}^{2-}$ conformer. Solution state ${ }^{1} \mathrm{H}-\mathrm{NMR}$ titration studies establish 1:1 (host/guest) binding between receptor and $\mathrm{C}_{2} \mathrm{O}_{4}^{2-}$ in semi-aqueous solvent. All the receptors bind $\mathrm{C}_{2} \mathrm{O}_{4}^{2-}$ with high binding constant $\left(\sim 10^{4}\right)$ in semi-aqueous solvent.

\section{Supplementary Information}

Spectral data $\left({ }^{1} \mathrm{H},{ }^{13} \mathrm{C}\right.$ NMR) for complex $\mathbf{1}$ and $\mathbf{2}$ are provided. Crystallographic table, selected geometric parameter and hydrogen bonding table for complex $\mathbf{1}$ and $\mathbf{2}$ are also provided. Equivalent plots of ${ }^{1} \mathrm{H}-\mathrm{NMR}$ titration data for $\mathbf{L} \mathbf{1}$ and $\mathbf{L} 2$ with $\mathrm{C}_{2} \mathrm{O}_{4}^{2-}$. The electronic supplementary information can be seen at www.ias.ac. in/chemsci.

\section{Acknowledgements}

P G gratefully acknowledges the Department of Science and Technology (DST), New Delhi, India for financial support through a Swarnajayanti Fellowship. R D acknowledges DST, India for a fellowship. B C would like to acknowledge the Council of Scientific and Industrial Research (CSIR), New Delhi, India for fellowship. $\mathrm{X}$-ray crystallography is performed at the DST funded National Single Crystal X-ray Diffraction Facility in the Department of Inorganic Chemistry, IACS.

\section{References}

1. (a) Janausch I G, Zientz E, Tran Q H, Kröger A and Unden G 2002 Biochim. Biophys. Acta, Bioenerg. 39 1553; (b) Yurgel S N and Kahn M L 2004 FEMS Microbiol. Rev. 28489

2. Libert B and Franceschi V R 1987 J. Agric. Food Chem. 35926

3. (a) Holmes R P and Kennedy M 2000 Kidney Int. 57 1662; (b) Al-Wahsh I A, Harry H T, Palmer R G, Reddy M B and Massey L K 2005 J. Agric. Food Chem. 53 5670

4. (a) Bean P A 2012 J. Chem. Educ. 89 417; (b) Dinnebier R E, Vensky S, Panthöfer M and Jansen M 2003 Inorg. Chem. 421499

5. (a) Nelson J, Nieuwenhuyzen M, Pál I and Town R M 2004 Dalton Trans. 229; (b) Mateus P, Delgado R, Brandão P and Félix V 2011 Chem. Eur. J. 17 7020; (c) Mateus P, Delgado R, Brandão P and Félix V 2012 J. Org. Chem. 774611

6. (a) Tang L, Park J, Kim H -J, Kim Y, Kim S J, Chin J and Kim K M 2008 J. Am. Chem. Soc. 130 12606; (b) Hu M and Feng G 2012 Chem. Commun. 48 6951; (c) Rhaman M M, Fronczek F R, Powell D R and Hossain M A 2014 Dalton Trans. 434618

7. Jiménez M B, Alcázar V, Peláez R, Sanz F, Arriba Á L F and Caballero M C 2012 Org. Biomol. Chem. 101181

8. (a) Raposo C, Almaraz M, Martín M, Weinrich V, Mussõns M L, Alcázar V, Caballero M C and Morán J R 1995 Chem. Lett. 759; (b) Custelcean R, Moyer B A and Hay B P 2005 Chem. Commun. 5971; (c) Lakshminarayanan P S, Suresh E and Ghosh P 2006 Inorg.Chem. 45 4372; (d) Lakshminarayanan P S, Ravikumar I, Suresh E and Ghosh P 2007 Chem. Commun. 5214; (e) Jose A, Kumar K, Ganguly B and Das A 2007 Inorg. Chem. 46 5817; (f) Custelcean R, Remy P, Bronnesen P V, Jiang D and Moyer B A 2008 Angew. Chem., Int. Ed. 47 1866; (g) Ravikumar I, Lakshminarayanan P S, Arunachalam M, Suresh E and Ghosh P 2009 Dalton Trans. 4160; (h) Custelcean R, Bock A and Moyer B A 2010 J. Am. Chem. Soc. 132 7177; (i) Busschaert N, Gale P A, Haynes C J E, Light M E, Moore S J, Tong C C, Davis J T and Harrell Jr. W A 2010 Chem. Commun. 46 6252; (j) Ravikumar I and Ghosh P 2010 Chem. Commun. 46 1082; (k) Dey S K and Das G 2011 Chem. Commun. 47 4983; (1) Dey S K and Das G 2011 Dalton Trans. 40 12048; (m) Pramanik A, Powell D R, Wong B M and Hossain M A 2012 Inorg. Chem. 51 4274; 
(n) Dutta R, Bose P and Ghosh P 2013 Dalton Trans. 42 11371; (o) Busschaert N, Wenzel M, Light M E, Hernández P-I, Tomás R-P and Gale P A $2011 \mathrm{~J}$. Am. Chem. Soc. 133 14136; (p) Arunachalam M and Ghosh P 2011 Chem. Commun. 47 8477; (q) Bose P, Dutta R, Santra S, Chowdhury B and Ghosh P 2012 Eur. J. Inorg. Chem. 5791; (r) Akhuli B, Ravikumar I and Ghosh P 2012 Chem. Sci. 3 1522; (s) Custelcean R 2013 Chem. Commun. 49 2173; (t) Bose P, Dutta R and Ghosh P 2013 Org. Biomol. Chem. 114581

9. (a) SAINT and XPREP, 5.1 ed; Siemens Industrial Automation Inc.: Madison, WI, 1995 Sheldrick G M; (b) SADABS, Empirical absorption correction program; University of Göttingen: Göttingen, Germany, 1997
10. Sheldrick G M 1997 SHELXTL Reference manual: Version 5.1; Madison, WI: Bruker AXS

11. Sheldrick G M 1997 SHELXL-97: Program for crystal structure refinement; University of Göttingen: Göttingen, Germany

12. Spek A L 1997 PLATON-97; University of Utrecht: Utrecht, The Netherlands

13. Mercury 2.2 supplied with Cambridge Structural Database, CCDC, Cambridge, UK

14. (a) Olsen J A, Banner D W, Seiler P, Sander U O, D'Arcy A, Stihle M, Müller K and Diederich, F 2003 Angew. Chem. Int. Ed. 42 2507; (b) Fischer, F R, Schweizer W B and Diederich, F 2007 Angew. Chem. Int. Ed. 46 8270 